\title{
Die brief aan Rheginos: Oor geloof en rede en die opstanding
}

\author{
Willem S Vorster
}

\section{Abstract}

The letter to Rheginos: On faith and reason and the resurrection The article consists of an introduction to and an Afrikaans translation of the Coptic Epistle to Rheginos on the resurrection. It is dedicated to Professor JAAA Stoop as a token of appreciation for his contribution to promote the study of early Christian literature in South Africa.

\section{Hierdie artikel word opgedra aan professor JAAA Stoop uit erkentlikheid vir sy bevordering van die studie van die geskiedenis van die vroeë Christene deur middel van hulle geskrifte.}

Die gedagte om hierdie artikel aan professor Jan Stoop op te dra, het sy oorsprong gehad in my gaslesin ling A) van die Universiteit van Pretoria gedurende Augustus 1985. By daardie geleentheid het ek vir studente van die Nuwe Testament probeer aantoon wat die waarde van buitebybelse geskrifte vir die bestudering van die Nuwe Testament is. In my behandeling van die saak het ek groot klem laat val op die resepsie van die Nuwe Testament en Nuwe-Testamentiese tradisies in die geskrifte van die vroeë Christendom. Daardeur het ek probeer aantoon hoe die vroeë kerk, deurdat hulle die geskrifte van die Nuwe Testament kreatief gelees het, geteologiseer het en in nuwe situasies uit ou tekste nuwe tekste geskep het. Die doel van die lesings was om die studente te laat besef dat die lees van die Nuwe Testament ' $n$ skeppende en nie ' $n$ statiese proses is nie en dat dit reeds vanaf die vroegste tye so was. Die bestudering van die resepsie en werking van die geskrifte van die Nuwe Testament verbreed nie alleen ons kennis oor die wording van die kerk nie, dit verruim ook terselfdertyd ons visie oor wat die Nuwe Testament self is en hoe dit as oorsprongsdokumente aanleiding gegee het tot refleksie oor wat Christene glo en op grond waarvan hulle sekere dinge glo. Ek het verder probeer aantoon hoe jammer dit is dat leerstoele in die 
Nuwe Testament by Suid-Afrikaanse universiteite en derhalwe die dosering van die Nuwe Testament beperk is tot die korpus geskrifte van die Nuwe Testament en nie byvoorbeeld die vroeg-Christelike literatuur insluit nie. Een van die temas wat ek behandel het, was die opstanding by Paulus. Om die saak godsdienshistories in reliëf te plaas en die werking van die uitsprake van Paulus in die vroeë kerk aan te dui, het ek ook die sogenaamde Brief aan Rheginos wat uit die Koptiese versameling van Nag Hammadi afkomstig is, behandel. Dit is na aanleiding hiervan dat my gedagtes onwillekeurig teruggegaan het na my eerste akademiese ontmoeting met Jan Stoop toe ek in 1971 by Unisa aangesluit het en dat ek besluit het om uit waardering vir sy bydrae tot die bevordering van die studie van die vroeë Christelike geskrifte 'n artikel aan hom op te dra. Dit was op grond van 'n opmerking van wyle professor Ian Eybers oor Jesus tydens ' $n$ fakulteitslesing oor Jona dat daar besluit is dat ek die volgende lesing oor Jesus se uitsprake oor Jona in Matteus 12:38-42 sou lewer en Stoop daarna oor Jona in die vroeë kerk (vgl Eybers 1971: 211-222; Vorster 1971: 223-235 en Stoop 1972: 49-65). Reeds toe het ek besef dat daar ' $n$ baie groot gemeenskaplike belangstelling tussen professor Stoop en my bestaan, omdat albei van ons per definisie tekswetenskaplikes en historici wil wees. My waardering vir hom het veral betrekking op die feit dat hy die vroeë kerk aan die hand van die skriftelike nalatenskap daarvan bestudeer. Sy intense interesse in primêre bronne in plaas van bronne oor die vroeë Christene het my grootste waardering. In die lig hiervan het ek besluit om 'n artikel te skryf waarin ek nie my en andere se menings gaan gee oor die waarde van buitebybelse geskrifte vir die bestudering van die Nuwe Testament nie, maar om ' $n$ vertaling te maak van 'n dokument uit die vroeë kerk wat professor Stoop na alle waarskynlikheid nog nie gelees het nie. Sodoende kan ek iets aan hom opdra by geleentheid van sy emeritaat waarvoor hy hom in sy akademiese loopbaan beywer het - die bestudering van die vroeg-Christelike kerk aan die hand van oorspronklike bronne.

Die artikel val vervolgens uit in twee dele. In die eerste deel word daar 'n uiteensetting gegee van die agtergrond waarteen die Brief aan Rheginos gesien moet word. Die tweede deel bevat ' $n$ vertaling van die geskrif in Afrikaans. Dit is ' $n$ vertaling van die Koptiese teks soos uitgegee deur Malinine, Puech, Quispel en Till (1963).

Die ontdekking van 'n versameling Koptiese geskrifte gedurende Desember 1945 (vgl Robinson 1979) in die omgewing van Nag Hammadi 
ongeveer 100 kilometer noord van die bekende Luxor in Egipte, het om verskeie redes nie soveel belangstelling uitgelok as die ontdekking van die sogenaamde Dooie See-Rolle in Palestina 'n paar jaar later nie. Dit sou ongeveer dertig jaar duur voordat die omstandighede rondom die toevallige ontdekking van 'n groot kruik met twaalf of dertien ou papirusboeke deur 'n Egiptiese boer, ene Mohammed Ali es-Sammân en sy broers, na bevrediging gerekonstrueer kon word en net so lank voordat die versameling geskrifte uitgegee en aan die wetenskaplike wêreld beskikbaar gestel is. Desnieteenstaande kan daar vandag sonder enige twyfel beweer word dat hierdie ontdekking een van die belangrikste bydraes gelewer het tot ' $n$ beter insig in die wording van die kerk en veral ten opsigte van ons kennis van die gnostiek. Die belangrikste rede waarom hierdie versameling geskrifte nog nie die aandag van kerkhistorici ontvang het wat dit toekom nie, is die feit dat die dokumente in Kopties geskryf is en gevolglik ontoeganklik is vir baie kenners van die geskrifte van die vroeë kerk. Hoewel daar ook ander redes mag bestaan, verklaar dit miskien ook die feit waarom die Nag Hammadi-tekste, ten spyte van die belangrikheid van die inligting daarin vervat, nog weinig aandag in Suid-Afrika ontvang het.

Hierdie versameling, wat intussen bekend geraak het as die Nag Hammadi-'biblioteek', bestaan uit twee en vyftig antieke geskrifte, in dertien papirus-boeke saamgebundel, waarvan veertig vroeër totaal onbekend was. Die groot meerderheid is Christelik-gnostiese en gnostiese geskrifte, maar daar is selfs 'n swak vertaling van Plato se Republiek in die versameling gevind. As ' $n$ mens in ag neem dat voor die ontdekking van Nag Hammadi daar, naas die fragmente van gnostiese geskrifte in die geskrifte van die kerkvaders en enkele ander geskrifte, soos die Evangelie van Maria, die Apokrufon van Johannes, die Sofia van Jesus Christus, die Pistis Sofia en die Boeke van Jeû, geen ander gnostiese geskrifte aan ons bekend was nie, spreek die waarde van hierdie ontdekking vanself. Ons kennis oor die gnostiek was hoofsaaklik gegrond op die verwerping en bevegting van die gnostisisme deur kerkvaders soos Origenes, Irenaeus, Hippolitus, Klemens van Aleksandrië en Epifanius. Vanweë die vanselfsprekende beperkinge op ons kennis van en insig in die gnostiek en die vroee kerk wat hierdie situasie in die hand gewerk het, is dit nie vreemd dat daar vandag in verskeie kringe intensief en opnuut gekyk word na die oorspronge en aard van die gnostiek nie (vgl Van den Broek 1983). Hierdie ondersoeke is veral ten opsigte van die oorspronge en wording van die vroeë kerk van wesenlike belang. 
Die kerk het in 'n wêreld ontstaan waarin 'n menigte godsdienste en godsdienstige strominge aan die orde van die dag was. Hoewel die vroeë kerk vir baie mense 'n monolitiese geheel is waarin daar geen plek vir andersdenkendes was nie, blyk dit reeds uit die Nuwe Testament dat daar van die begin af verskille bestaan het oor wesenlike sake soos byvoorbeeld die opstanding. Saam met die Christendom was daar 'n godsdiens aan die ontwikkel wat baie met die Christendom in gemeen gehad het, maar ook baie daarvan verskil het, naamlik die so genoemde gnostisisme (vgl Jonas 1969). Wat die presiese verhouding tussen die Christelike godsdiens en gnostisisme was, is baie moeilik om te bepaal. Dit is egter duidelik dat dit net so moeilik is om te onderskei tussen Christene en gnostici aan die beginfases van die kerk as wat 'n mens ' $n$ onderskeid sou kon maak tussen ortodoksie en ortopraksie aan die een kant en heterodoksie en heteropraksie aan die ander kant in die vroeë kerk (vgl Bauer 1964). Van den Broek (1983: 50) merk tereg op dat daar heiden- en Christen-gnostici was en dat daar onder die Christene gnostiese Christene en nie-gnostiese Christene was en trouens, dat iemand soos die bekende Valentinus uit die helfte van die tweede eeu na Christus homself beslis as 'n Christen sou beskou het. Dat gnostisisme uiteindelik ontwikkel het tot ' $n$ spekulatiewe teologiese sisteem wat deur die kerk as kettery verwerp is, is bekend. Dit is teen hierdie agtergrond dat daar na die Nag Hammadigeskrifte en by name die Brief aan Rheginos gekyk moet word, omdat sommige van die geskrifte kennelik die denke van Christen-gnostici verteenwoordig terwyl ander deur en deur die produk van gnostiese teologiese spekulatiewe denke is.

Die Nag Hammadi-geskrifte is gedurende die vierde eeu deur Pagomiese monnike uit verskillende oorde versamel. Hulle het hierdie geskrifte wat uiteenlopend van aard is, waarskynlik gelees om opgebou te word (vgl Van den Broek 1983: 47). Dit is op sigself interessant, omdat daar vroeër gedink is dat hierdie monnike ortodokse Christene was. Hoewel daar nog dikwels van die Nag Hammadi-'biblioteek' gepraat word en die indruk daardeur gelaat word dat dit ' $n$ versameling van eenderse geskrifte is, moet dit herhaal word dat die dokumente uiteenlopend van aard is (vgl Kraft en Timbie 1982).

Die hele versameling bestaan uit Koptiese vertalings van geskrifte wat oorspronklik in Grieks geskryf is en waarvan sommige ook inderdaad nog in hulle oorspronklike Griekse vorm bekend is. Kopties is 'n vorm van Egipties wat in 'n uitgebreide vorm van die Griekse alfabet geskryf is. Dit is die taal waarin die literêre aktiwiteit vanaf die derde 
tot en met die tiende eeu na Christus in Egipte plaasgevind het. Dit is egter as gevolg van die verowering van Egipte deur die Arabiere (641 $\mathrm{n} \mathrm{C)} \mathrm{deur} \mathrm{Arabies} \mathrm{verdring,} \mathrm{hoewel} \mathrm{Kopties} \mathrm{tot} \mathrm{vandag} \mathrm{toe} \mathrm{die} \mathrm{taal} \mathrm{van}$ die Koptiese Kerk gebly het. Daar was verskillende dialekte waarvan Sahidies die belangrikste was. Daarnaas het Bohaïries (die huidige kerktaal), Agmimies, Subagmimies en Fajjumies ook as dialekte van Kopties in Egipte 'n rol gespeel. Met die oog op die agtergrond waaruit die Nag Hammadi-geskrifte afkomstig is, is die feit dat hulle Koptiese vertalings is, nie onbelangrik nie. Hoewel die Koptiese versameling uit die vierde eeu afkomstig is en dit as sodanig vir ons iets sê oor ortodoksie en heterodoksie in die kerk in Egipte, is die voorgeskiedenis van die geskrifte nog belangriker omdat hulle in hulle oorspronklike vorm baie vroeër ontstaan het. 'n Goeie voorbeeld hiervan is die so genoemde Evangelie van Tomas waarvan ' $n$ Koptiese vertaling ook in die Nag Hammadi-versameling gevind is. Dit geld egter ook van die Brief aan Rheginos soos ons hieronder sal sien.

Die Brief aan Rheginos vorm saam met ander geskrifte, soos die Brief van Jakobus, Die Evangelie van Waarheid en die Verhandeling oor die Drie Nature, deel van Kodeks I (bl 43-50) van die Nag Hammadi-versameling. Spoedig na die ontdekking van die geskrifte is Kodeks I as gevolg van 'n sameloop van omstandighede van die res van die kodekse geskei. Die gevolg was dat 100 van die 136 bladsye van Kodeks I in Zürich in die Jung Instituut beland het en bekend geword het as die so genoemde Kodeks Jung terwyl die res in Kaïro in die Koptiese museum agtergebly het. Onder die 100 bladsye wat in Zürich tereggekom het, was daar ses van die agt bladsye van die Brief aan Rheginos (vgl Haenchen 1964 en Peel 1969: 1-3). Dit was egter moontlik om op grond van 'n ooreenkoms tussen belanghebbende partye al agt bladsye van die geskrif gelyktydig uit te gee. Dit is op hierdie uitgawe, soos ek hierbo vermeld het, wat ek my vertaling gebaseer het. Kodeks I is op grond van die genoemde ooreenkoms teruggestuur na Kaïro waar dit saam met die ander kodekse bewaar word.

Die Brief aan Rheginos is uit Grieks in Subagmimies vertaal. Hierdie dialek is sedert die middel van die derde tot die vyfde eeu na Christus in die omgewing van Assiût, ongeveer 160 kilometer noord van Nag Hammadi, as taal gebruik. Dit is waarskynlik dat Assiût 'n area was waar verskillende gnostiese dokumente ontstaan het en versprei is, hoewel daar ook verskillende ortodoks-Christelike manuskripte in Subagmimies gevind is. Daarbenewens was daar verskillende monnike-ordes en gemeenskappe in die omgewing van Assiût (vgl Peel 
1969: 4) in hierdie tyd. Die teenwoordigheid van 'n redelike groot aantal Griekse terme in die teks van Rheginos (vgl die lys by Malinine et al 1963: 68) moet aan die feit toegeskryf word dat dit 'n vertaling uit Grieks is, selfs al het Kopties van baie Griekse leenwoorde gebruik gemaak. Dit is belangrik om op te merk dat die oorspronklike Griekse dokument nie meer voorhande is nie en dat die geskrif slegs uit die Nag Hamaddi-versameling bekend is.

Wie die oorspronklike skrywer van die Brief aan Rheginos was, is totaal onbekend. Daar is geen interne getuienis in die dokument self waaruit daar enige afleidings oor die skrywer of datum van skrywe gemaak kan word nie. Hy rig die geskrif aan ene Rheginos van wie ons ook geen ander kennis het nie. Rheginos word direk (vgl 44: 22; verwysings volgens bladsy en reël in Kodeks I) of as 'my seun' (vgl 43: 25; 46: 6) aangespreek en die indruk word gelaat dat daar ' $n$ besondere verhouding tussen hom en Rheginos, soos dié tussen 'n leermeester en leerling, bestaan het. Dit word in 'n groot mate bevestig deur die inhoud van die geskrif wat hoofsaaklik bestaan uit antwoorde op konkrete vrae oor die opstanding. Op grond van die feit dat die geskrif kennelik verwantskap vertoon met gedagtes wat aan Valentinus (vgl Layton 1980) toegeskryf word en die feit dat dit oorspronklik in Grieks geskryf was, is die vermoede uitgespreek dat dit deur Valentinus self geskryf kon gewees het (vgl Malinine et al 1963 xxv vv). Hierdie hipotese is interessant, maar daar bestaan nie genoeg grond daarvoor nie. Ook wat die datum van skrywe betref, bestaan daar geen konkrete gegewens nie. Aangesien daar direk na Paulus verwys word (vgl 45), moes die geskrif ná Paulus geskryf gewees het. Dit word ook bevestig deur die Pauliniese denkraam waarbinne die inhoud gebed lê (vgl Koschorke 1981). Dit beteken egter slegs dat ons weet dat die dokument ná Paulus geskryf is. Waar en wanneer bly onbekend. Aangesien die opstanding die tema onder bespreking was in die kerk gedurende die tweede eeu, is dit waarskynlik dat die Brief aan Rheginos iewers gedurende die tweede eeu in die Romeinse Ryk ontstaan het (vgl Van Unnik 1964: I \& II ook Layton 1979: 2 vv).

Hoewel die geskrif bekend staan as die Brief aan Rheginos, bestaan daar uiteenlopende menings oor die genre van die dokument. Dit het geen normale briefaanhef nie en aan die slot word daar na die groete as 'n naskrif, soos by verskillende ander geskrifte van Nag Hammadi, 'n titel vermeld, naamlik: plogos etbe tanastasis - die diskoers oor die opstanding. Dit vertoon egter nietemin die kenmerke van briewe uit die Hellenisties-Romeinse tydperk. Verskillende persone het daarop 
gewys dat die dokument met die diatribe-styl ooreenkom (vgl Van Unnik 1964 I: 146 en Martin 1973). Die inhoud wat oor die opstanding handel, bestaan uit 'n algemene inleiding (43: 25-44: 3), die tema (44: $3-12)$, argument (44: 12-47: 1), samevatting (47: 1-4), weerlegging (47: 4-49: 9), paranese (49: 9-36) en die epiloog (49: 37-50: 16). Die materiaal, wat hoofsaaklik bestaan uit.'n diskoers oor die opstanding, is in die vorm van argumentasie en uitleg georganiseer. 'n Konkrete vraag gee aanleiding tot ' $n$ uitleg van die probleem. Of ons die geskrif derhalwe ' $n$ brief of ' $n$ verhandeling noem, is nie so belangrik nie as die feit dat die materiaal sodanig georganiseer is dat dit die leser moes oortuig dat die opstanding noodsaaklik is en dat die opstanding reeds plaasgevind het voordat die leser nog selfs te sterwe gekom het. Hierdie standpunt tref ons reeds in die Nuwe Testament aan waar dit van die hand gewys word (vgl 2 Tim 2: 16-17). Wat vorm betref, herinner die geskrif 'n mens aan die so genoemde Hebreërbrief in die Nuwe Testament.

Dat daar reeds ten tye van die ontstaan van die Nuwe Testament interpretasieprobleme oor die opstanding ontstaan het, is voor-diehand-liggend. Dit blyk onder andere uit die vertelling oor die leë graf sowel as die wyse waarop Paulus in 1 Korintiërs 15 oor die opstanding skryf. In 2 Timoteus 2: 16-17 lees ons:

Maar die onheilige en sinlose praatjies moet jy vermy, want die wat dit versprei, sal nog verder in goddeloosheid verval, en hulle woorde sal voortvreet soos kanker. Onder hulle is daar Himeneus en Filetus, wat van die waarheid afgedwaal het deur te sê dat die opstanding alreeds plaasgevind het. Daarmee vernietig hulle die geloof van sommige (NAV).

Die verskille het egter in die tweede eeu 'n hoogtepunt bereik toe die geloof in die opstanding die saak geword het waarby die geloof gestaan of geval het (vgl TertResCarn 3; OrCels; JustApol en AthenRes). Die Brief aan Rheginos is geen uitsondering nie en tog verskil dit in baie opsigte van die pogings van teoloë uit die tweede eeu wat die opstanding probeer verduidelik en verdedig het. Terwyl baie van die genoemde geskrifte breedvoerige verdedigings bevat oor detail in verband met die opstanding, het die skrywer van Rheginos homself beperk tot die beantwoording van konkrete vrae wat in die gemoed van Rheginos opgekom het.

Een van die uitstaande kenmerke van die geskrif is die feit dat die skrywer die opstanding direk in verband met Jesus Christus en die 
geloof in Hom bring ten spyte van die gnostiese kleed waarin die skrywer die opstanding klee (vgl Zandee 1962). Volgens die skrywer berus die opstanding op die opstanding van Christus (vgl 45: 14) wat die weg tot onsterflikheid voorberei het (45: $17 \mathrm{vv})$. Die mens wat in Christus glo, het reeds opgestaan (49: $13 \mathrm{vv}, 22 \mathrm{vv}$ ) en sal gered word (46: $25 \mathrm{vv}$ ). Ook die liggaam het deel aan die opstanding (vgl 47: 4-10). Dit is opmerklik dat hy 'n baie sentrale plek aan Jesus toeken. Jesus word 'Here', 'Redder' en 'Christus', dit is 'die goeie' genoem. Die opstanding staan in verband met die opstanding van Jesus wat sowel mens as God is. Daar is geen sprake van 'n dosetiese Christologie in die geskrif nie hoewel die gnostiese ondertone dat Jesus die saad van waarheid is, nie misgekyk moet word nie. 'Seun van God' en 'Seun van die mens' druk die goddelike en menslike aspekte van Jesus uit sonder dat daar enige aanduiding is waarna hierdie name binne die verwysingsraamwerk van die skrywer verwys. Dit is opmerklik dat die term 'seun van die mens' slegs betrekking het op die mensheid van Christus en glad nie in verband met die funksie van Jesus as regter by die opstanding gebring word nie. Trouens, die opstanding word in hierdie geskrif nie in verband met die oordeel gebring nie.

Anders as baie ander Christelike skrywers uit sy tyd, probeer hy nie die geloof met die rede begrond deur allerlei bewyse uit die natuur aan te voer (vgl 1C 32) en ellelange argumente voor te lê oor hoe die opstanding van die vlees, van mense wat byvoorbeeld in die see vergaan het, moontlik sou wees nie (vgl daarenteen Athen Res $4.1 \mathrm{vv}$ ). Op 'n heel nugter wyse argumenteer hy dat die opstanding nie 'n saak van oorreding nie, maar van geloof is (46). Sowel die klem op die geloof as die feit dat dit nie 'n saak vir die rede is nie, is besonder opvallend vir 'n gnostiese Christen wat kennelik goed tuis was in die Valentynse godsdienstige refleksie. Laasgenoemde blyk nie alleen uit die gebruik van tipiese simbole van die gnostiek soos 'rus', 'volheid' (pleroma), 'al', 'waarheid' en so meer nie, maar ook deur die wyse waarop die werklikheid simbolies funksioneer.

Die opskrif van my artikel is na aanleiding van die beklemtoning van die geloof sonder die rede in die Brief aan Rheginos gekies. Dit is veral wanneer 'n mens die genoemde diskussies oor die opstanding gedurende die tweede eeu lees dat 'n mens besef hoe anders hierdie geskrif met die saak omgaan. Ten spyte van die gnostiese kleed waarin sommige voorstellings aangebied word, kry 'n mens die indruk van hoe moeilik dit vir Christene in die vroeë kerk was om rasioneel met die opstanding om te gaan. Dat dit by uitstek een van die gebiede in die 
Christelike geloof was wat aanleiding gegee het tot spekulatiewe teologiese refleksie van uiteenlopende aard, is daarom nie vreemd nie. Dat die skrywer van hierdie geskrif ten spyte van die genoemde gnostiese invloede nog binne die hoofstroom van die Christelike kerk probeer dink het, sal ook moeilik ontken kan word. Dit blyk duidelik uit 'n vergelyking met die spekulasie van 'hoofstroom'-teoloë, maar ook uit wat uiteindelik met die opstanding en by name met die voorstelling van Christus in die gnostisisme gebeur het. In hierdie opsig is die Brief aan Rheginos ' $n$ juweel uit die tweede eeu. In die plek van kennis staan geloof nog op die voorgrond, selfs al kan die plek van die rede nie in die geskrif ontken word nie.

Die voorafgaande oorsig is bedoel as ' $n$ inleiding en ' $n$ verwysingsraamwerk waarteen die vertaling wat hieronder volg, gelees kan word. Daar is gepoog om die vertaling so verstaanbaar moontlik te maak sonder om die oorspronklike geweld aan te doen. Soos enige vertaling is dit ' $n$ interpretasie van die gewerteks. Omdat ek die leser graag in die gees wou terugvoer na die Koptiese kodeks, het ek besluit om die bladsye en reëls van die oorspronklike dokument aan te dui. Dit het egter beteken dat ' $n$ werkwoord soms op 'n on-Afrikaanse manier in 'n sin geplaas is of dat sommige reëls in die Afrikaans nie presies ooreenkom met die Kopties nie. Waar moontlik het ek egter so na as moontlik aan die oorspronklike gehou sonder om woord vir woord te vertaal. Omdat ek gekies het om die Malinine-uitgawe te vertaal, het ek ook hulle konstruksie van die teks aanvaar. Konjekture word met vierkantige hakies aangedui en gnostiese terme wat vir die oningewyde leser onbekend is, word met 'n hoofletter geskryf en soms word daar 'n alternatiewe term tussen gewone hakies geplaas. Daar is egter deurgaans gepoog om te kies vir 'n spesifieke vertaling eerder as om alternatiewe tussen hakies te gee. In sommige gevalle was dit egter nie moontlik nie.

Bladsy 43

25 Rheginos, my seun, daar is sommige mense wat baie graag leer.

Dit is ook hulle bedoeling wanneer hulle probleme aanpak waarvoor daar nie oplossings bestaan nie. En 
30 wanneer hulle oplossings vind, dink

hulle gewoonlik baie van

hulleself. Ek dink egter nie dat

hulle hulle ankers in

die leer van die waarheid gehad het nie. Hulle soek

35 eerder hulle Rus. Dit

het ons ontvang deur ons Red-

der, ons Here Christus (die Uitmuntende).

Bladsy 44

Ons het dit ontvang toe ons die waarheid leer ken het en daarin (daarop) tot rus gekom het. Maar

aangesien jy ons vriendelik vra

5 wat gepas is

in verband met die opstanding, skryf ek

aan jou dat dit noodsaaklik is.

Daar is inderdaad baie mense

wat nie in die opstanding glo nie

10 en verder is daar min wat hierdie geloof vind.

Laat ons derhalwe die saak

bespreek. Hoe [h]et

die Here die dinge benut

terwyl Hy op

15 aarde was en nadat $\mathrm{Hy}$

hom ge-openbaar het as seun

van God? Hy het geloop

op die plek waar

jy nou leef en gepraat

20 oor die wet van die natuur. Ek

bedoel die dood. Die seun

van God, Rheginos,

was egter ook seun van die mens. En Hy

het hulle albei omvat.

25 Hy het mensheid

en $\mathrm{Hy}$ het godheid gehad

sodat $\mathrm{Hy}$ aan die een kant oorwinning kon behaal

oor die dood

deur seun van God te wees 
30 en aan die ander kant deur seun

van die mens te wees die herstel (terugkeer)

te laat plaasvind tot

die Volheid (Pleroma). (Dit is die geval) omdat

Hy oorspronklik van bo (hemel) was,

35 saad van die waarheid, voordat

hierdie struktuur tot stand gekom het

waarin heerskappye en

godhede talryk ge-

word het. Ek weet ek gee

Bladsy 45

'n oplossing vir moeilike

dinge, maar aan die ander kant is daar niks

moeiliks in die woord

van die waarheid nie. Aangesien die

5 oplossing egter gekom het

sodat niks verborge bly nie

en alles geheel en al

openbaar gemaak word oor

die bestaan (syn): die vernietiging

10 van die bose aan die een kant en aan die ander kant die openbaring van dit wat voortreflik is. Dit is die openbaring van die waarheid en

die Gees. Hierdie genade is van die w[aar]heid afkomstig.

Die Redder het die dood verswelg.

15 Hier moet jy nie onkundig wees nie,

want $\mathrm{Hy}$ het die kosmos (wêreld) van die hand gewys

wat tot niet gaan. Hy het [hom] verander in

'n onverganklike Aion (bestaan). Hy

het homself opgewek en (so)

20 die sigbare verswelg

deur die onsigbare en

vir ons die pad geopen

tot ons onsterflikheid.

Dus, soos die apostel

25 gesê het: Ons het saam met hom

gely en ons het saam met hom opgestaan

en ons het saam met hom opgegaan na die hemel. 
As ons openbaar

gemaak word in

30 hierdie wêreld terwyl ons met hom bekleed is,

is ons sy strale

en ons word

deur hom omvat totdat ons ondergaan, dit is

35 tot ons sterwe in hierdie le-

we. Ons word na die hemel opgetrek

deur hom soos strale

deur die son sonder

dat iets ons terughou. Dit is die

40 geestelike opstanding

Bladsy 46

wat die psigiese verswelg

tesame met die vleeslike.

As daar iemand is wat

nie glo nie, is dit onmoontlik om hom te

5 oortuig. Want hier moet 'n mens glo,

my seun, dit is nie die plek vir

oortuiging (rede) nie. Iemand wat dood is, sal

opstaan. En is daar iemand

onder die filosowe hier (op aarde) wat glo,

10 maar natuurlik sal hy opstaan. En laat die filosoof wat hier op aarde is nie glo

hy is iemand wat [h]omself laat terugkeer nie en (dit) oor ons geloof.

[O]ns ken immers die seun van

15 die mens en het die geloof dat

Hy opgestaan het uit

die dood. En Hy is die een van wie ons sê:

Hy het die dood se ondergang beteken.

Soos die een in wie

20 daar geglo word groot is, is hulle wat glo in Hom.

Die nadenke van hulle wat gered

word sal nie tot niet gaan nie.

Die bewussyn van hulle wat weet, sal nie vergaan nie.

25 Daarom is ons uitgekies met die oog op ons redding en verlossing. 
Dit is vanaf die begin vir ons bepaal dat ons nie val in die dwaasheid van die wat onkundig is nie.

30 Maar ons sal ingaan in die wysheid van hulle wat die waarheid ken. Die waarheid wat hulle bewaar, kan onmoontlik laat vaar word.

Dit sal ook nie gebeur nie.

35 Sterk is die struktuur van die Volheid (Pleroma), klein is dit wat homself ontkoppel het en die wêreld geword het. Die $\mathrm{Al}$ (alles) is dit wat behou is. [D] it het nie geword nie,

Bladsy 47

dit was. Dus:

moenie twyfel oor

die opstanding nie, my seun Rheginos.

Want as jy nie bestaan het in

5 vlees nie, het jy vlees geword toe jy

die wêreld ingegaan het. Waarom

sal jy nie vlees ontvang nie wanneer jy

opgaan in die ewigheid (aion).

Dit wat beter is as die vlees

10 is die oorsaak van die lewe.

Is dit wat ter wille van jou ontstaan

nie joune nie? En bestaan dit wat joune is

nie saam met [jou] nie?

Maar terwyl jy op aarde is, wat

15 ontbreek jou? Is dit wat jy jou

beywer het om te leer,

die nageboorte van die liggaam,

dit is die ouderdom? En

jy is korrupsie? Vir jou

20 is om afwesig te wees wins.

Jy sal immers nie dit wat voortreflik is, teruggee

wanneer jy sou vertrek nie. Die ondergeskikte

word geminag,

maar daar is genade. Niks

25 red ons derhalwe van

die aarde (hier) nie behalwe 
die Al waarvan ons deel is. Ons word gered. Ons het verlossing ontvang van die begin tot die einde. Laat ons dus op hierdie

30 wyse dink. Laat ons op hierdie manier verstaan. Daar is egter sommige wat wil verstaan wanneer hulle vrae vra oor die dinge wat hulle ondersoek of 'n persoon wat gered word terwyl hy sy

35 liggaam agterlaat onmiddellik gered word. Moenie dat iemand hieroor twyfel nie.

Dus, die dooie lede wat gesien kan word, sal

Bladsy 48

nie gered word nie, maar die lewende le[de] wat binne-in hulle is, hulle sal opstaan. Wat is die opstanding dan? Dit is die openbaring,

5 op enige moment, van die wat opgestaan het. As jy onthou dat jy in die Evangelie lees dat Elia verskyn het en Moses

10 saam met hom, moenie dink dat die opstanding fantasie is nie. Dit is nie 'n illusie nie. Dit is 'n feit (waarheid). Dit is eerder gepas om te beweer dat die

15 wêreld 'n illusie is, eerder as die opstanding wat sy oorsprong het deur ons Here, die Redder, Jesus Christus. Waaroor

20 lig ek jou nou in?

Hulle wat leef, sal sterf. Hoe leef hulle in 'n illusie? Die rykes het arm geword

25 en konings is ont- 
troon. Alles verander.

'n Illusie, dit is wat

die wêreld is. Maar laat

ek nou nie te veel afkeurend praat oor

30 die dinge (van die wêreld) nie. Kortom,

die opstanding is nie

van hierdie aard nie,

dit is ' $n$ feit (werklikheid) en dit staan vas.

Dit is ' $n$ openbaring van

35 dit wat bestaan, en die transformasie van

dinge. Dit is die

oorgang tot 'n nuwe bestaanswyse. Onverganklikheid

Bladsy 49

[ ] daal immers neer op

ver[gan]klikheid. En lig

vloei neer op die duisternis en

verswelg dit. Die

5 Volheid hef die gebrek op.

Hierdie dinge is die simbole en

beelde van die opstanding.

$\mathrm{Hy}$ is die een wat dit wat

goed is, skep. Moet dus nie

10 die dinge gedeeltelik bedink nie, Rheginos.

Jy moet ook nie in ooreenstemming

met hierdie vlees leef nie, nie ter wille van

eenheid nie. Vlug eerder weg

van die verdeeldheid en

15 die kettings en jy sal reeds

die opstanding hê. Immers, as

hy wat sterf homself

weet dat hy sal

sterf - selfs al leef hy

20 baie jare in hierdie lewe

word hy daartoe gebring -

waarom beskou jy jouself nie as

iemand wat opgestaan het

en daartoe gebring is nie?

25 As jy die opstanding reeds het maar voortgaan asof 
jy gaan sterf - en tog daardie mens weet

dat hy gaan sterf - waarom

verontagsaam ek jou gebrek

30 aan oefening? Dit is reg

dat elkeen op baie maniere

sal oefen, en

vrygemaak word van hierdie substansie (element)

sodat hy nie dwaal nie maar

35 homself opnuut sal neem

soos wat hy oorspronklik was.

Hierdie dinge het ek ontvang deur die

milddadigheid van my

Bladsy 50

Here Jesus, Chri[stus. Ek] het

jou en jou broers, my [kin-]

ders [gel]eer sonder om iets weg te laat

wat gepas is om julle te versterk.

5 As daar iets geskryf is

wat diepsinnig is in my uitleg van

die Woord, sal ek dit vir julle verduidelik

wanneer julle vra. Moet nou nie jaloers wees

op iemand wat aan jou behoort

10 en in staat is om te

help nie. Daar is baie wat kyk na

wat ek vir jou

geskryf het. Hierdie mense onderrig ek

oor vrede onder hulle en genade.

15 Ek groet jou en hulle wat julle lief-

het met broederlike liefde.

Die diskoers (logos) oor

die opstanding.

Baie van die werk wat professor Jan Stoop as kerkhistorikus verrig het, het bestaan uit die vertaling van veral Latynse tekste uit die vroeë kerk. Dit sal uiters jammer wees as hierdie vertalings nie op ' $n$ keer aan 'n breër leserskring bekend gestel word nie. Sy aandrang op Latyn as voorvereiste vir die BD-studie is verstaanbaar - nie alleen op grond van 
sy eie belangstelling nie, maar veral op grond van die skat van kennis wat dit oopmaak vir die studie van die vroeë Christendom. Dat hierdie skat egter baie ruimer is as die Latynse tekste blyk selfs uit ' $n$ geskriffie soos die Brief aan Rheginos. Daarbenewens is die bronne uit die Siriese en Griekse kerke van net soveel belang vir die ontsluiting van die wêreld van die vroeë Christendom. Dit wil egter voorkom asof die era waarin kennis van hierdie bronne voorvereiste was hier en elders in die wêreld aan die verbygaan is. Vir baie mense sal die geskrifte van die vroeë kerk gevolglik 'n geslote boek word. 'n Poging behoort myns insiens aangewend te word om hierdie geskrifte in vertaling onder die aandag van studente te bring. Afrikaanse vertalings van vroeg-Christelike geskrifte kan 'n bydrae lewer tot die skat van vertalings in Afrikaans. Dit sal prysenswaardig wees as daar'n poging deur kenners van die antieke tale en die Afrikaanse kerke aangewend word om soveel moontlik van hierdie geskrifte in vertaling beskikbaar te stel. In hierdie verband kan professor Jan Stoop nog 'n belangrike bydrae lewer.

\section{Literatuurverwysings}

BAUER, W 1964. Rechtgläubigkeit und Ketzerei im ältesten Christentum. Hrsg von G Strecker. 2. Aufl. Tübingen: Mohr.

EYBERS, I H 1971. The purpose of the book of Jonah. Theologia Evangelica 4, 211-222.

HAENCHEN, E 1964. Literatur zum Codex Jung. ThR 30, 39-82.

JONAS, H 1969. Het Gnosticisme. Utrecht: Het Spectrum.

KOSCHORKE, K 1981. Paulus in den Nag-Hammadi-Texten: Ein Beitrag zur Geschichte der Paulusrezeption im frühen Christentum. ZThK 78, 177-205.

KRAFT, R A \& TIMBIE, J A 1982. The Nag Hammadi Library: In English. Religious Studies Review 8, 32-52.

LAYTON, B 1979. The gnostic treatise on resurrection from Nag Hammadi. Missoula: Scholars Press.

LAYTON, B (ed) 1980. The rediscovery of gnosticism: Proceedings of the International conference on gnosticism at Yale New Haven, Connecticut, March 28-31, 1978. Vol. 1, The school of Valentinus. Leiden: Brill.

MALININE, M, PEUCH, H-C, QUISPEL, G \& TILL, W (eds) 1963. De Ressurrectione: Epistula ad Rheginum. Codex Jung F. XXII r-F. XXVv (p. 43-50). Zürich: Rascher Verlag.

MARTIN, L H 1973. "The treatise on the resurrection" (CG 1, 3) and diatribe style. VigChr $27,277-280$.

PEEL, M L 1969. The Epistle to Rheginos: A Valentinian letter on the resurrection. London: SCM.

ROBINSON, J M 1979. The discovery of the Nag Hammadi codices. BA 42, 206-224.

STEINDORFF, G 1921. Kurzer Abriss der Koptischen Grammatik: Mit Lesestücken und Wörterverzeichnis. Berlin: Reuther \& Reichard.

STOOP, J A 1972. Die Jona-figuur in die vroeg-Christelike Kerk. Theologia Evangelica 5, 49-65.

TILL, W C 1961. Koptische Dialektgrammatik: Mit Lesestücken und Wörterbuch. 2. Aufl. München: Beck. 
TILL, W C 1966. Koptische Grammatik: (saïdischer Dialekt): Mit Bibliographie, Lesestücken und Wörterverzeichnissen. 3. Aufl. Leipzig: VEB Verlag Enzyklopädie.

VORSTER, W S 1971. Matt. 12: $38 \mathrm{vv}$ en die historisiteit van die gegewens in Jona. Theologia Evangelica, 4, 223-235.

VAN DEN BROEK, R 1983. The present state of gnostic studies. VigChr 37, 41-71.

VAN UNNIK, W C 1964. The newly discovered gnostic 'Epistle to Rheginos' on the resurrection, I \& II. JEH 15, 141-153 \& 153-167.

ZANDEE, J 1962. De opstanding in de Brief aan Rheginos en in het Evangelie van Philippus. NedThT 16, 361-377. 